\title{
Evaluation of micronutrient potentials of seven commonly consumed indigenous spices from Nigeria
}

\author{
Omotayo, Olukemi Arike, Adepoju*, Oladejo Thomas, Keshinro, Oluremi O. \\ Department of Human Nutrition, Faculty of Public Health, College of Medicine, University of \\ Ibadan, Ibadan, Oyo State, Nigeria \\ *Corresponding Author e-mail address: tholadejo@yahoo.com \\ Telephone: (+234) 8033257333
}

\begin{abstract}
Micronutrient deficiencies remain a public health challenge globally, especially among developing countries of the world. Spices constitute an important part of daily diets of many populations but their nutritional roles are yet to be fully investigated. Micronutrient potentials of seven indigenous spices in Nigeria (Allium Ascalonicum, Piper guneensis, Aframomum melegueta, Zingiber officinale, Ocimum basilicum, Allium sativum, and Eugenia caryophyllata) were evaluated using standard methods of AOAC and atomic absorption spectrophotometry. The results revealed that $100 \mathrm{~g}$ edible portion of the spices contained between $15.5-91.1 \mathrm{~g}$ moisture, $0.29-1.77 \mathrm{~g}$ ash, $7.00-750.00 \mathrm{mg}$ calcium, $74.00-261.00 \mathrm{mg}$ phosphorus, $98.1-356.5 \mu \mathrm{g} \beta$-carotene and 7.30 - 38.30mg ascorbic acid. $O$ basilicum, $P$. guineensis and $A$. ascalonicum were very high in calcium content while $Z$. officinale, $O$. basilicum and $A$. melegueta were high in phosphorus and can be good sources of these minerals. All the spices were poor in iron and zinc, and might not make significant contribution to intake of these minerals. The spices can be good sources of $\beta$ carotene and ascorbic acids which are antioxidants. $100 \mathrm{~g}$ edible portion of the spices can contribute between $0.7-75 \%$ calcium, $9.8-35.7 \% \beta$-carotene, and $12.1-63.8 \%$ ascorbic acid to $\%$ RDAs of consumers, hence their consumption should be encouraged.
\end{abstract}

Keywords: Micronutrients, Indigenous spices, Micronutrient contribution, Antioxidants.

\section{INTRODUCTION}

Micronutrient malnutrition (hidden hunger) is particularly damaging (Eileen and Venkatesh, 2003), but can be eradicated or minimized through diet diversity strategy which is sustainable on the long term basis. Currently, three micronutrients (vitamin A, iron, and iodine) with the impact of zinc deficiency on growth, diarrhoea, and other health related issues have captured nutritionists' attention as being of public health concern (Underwood, 1999). Eating pattern and quality of staple foods can be improved through the enhancement of the sensory properties of foods (Sop et al., 2008).

Spices are exclusively of vegetable origin and occupy important position in the diet of human race (Fayemi, 1999). They are seed, fruit, bark or root of a plant which possess high fragrance and pungent aroma, being valued for their taste or smell, and when added to foods make them more palatable and stimulate digestion. Plants used as spices and condiments are usually aromatic and pungent (Achinewu et al., 1995), and these plants owe these properties to the presence of varying types of essential oils (Iwu, 1993; Macmillan, 1984). Spices and their herbs are used generally to prepare "pepper soups" which may be taken hot or cold especially during the cold and raining season, and are particularly very important in the diets of post-partum women as an aid to the contraction of the uterus (Achinewu, et al., 1995).

Commonly consumed indigenous spices in Nigeria include Allium Ascalonicum (Shallot), Piper guneensis (Black pepper), Aframomum melegueta (Alligator pepper), Zingiber officinale (Ginger), Ocimum basilicum (Sweet basil), Allium sativum (Garlic), and Eugenia caryophyllata (Clove). Allium Ascalonicum antiseptic properties as a juice or paste have been used in wound healing, acne, insect bites, haemorhoids, boils, and toothache among others. The fruits and leaves of Piper guineensis ('lyere' in Yoruba and 'Oziza' in Igbo languages (Ndukwu and 
Ben-Nwadibia, 2005) are used as spices for preparing soup for post-partum women and in treatment of vomiting, worm infestation, rheumatism and stomachache.

Raw Zingiber officinale is often masticated as a stimulant, stomach tonic, relief of congested nostrils and toothaches. It suppresses prostaglandin synthesis through inhibition of cyclooxygenase - 1 and cyclooxygenase - 2. In traditional Chinese and Indian medicine, Zingiber officinale has been used to treat a wide range of ailments including stomach aches, diarrhoea, nausea, asthma, respiratory disorders (Grzanna et al., 2005). Allium sativum is reported to cure ailments like fevers, coughs, constipation, asthma, nervous disorders, hypertension, ulcers and skin diseases (Ndukwu and Ben-Nwadibia 2005). Eugenia caryophyllata possesses a hot spicy flavour and a pungent aroma, (Fayemi, 1999) and is used in flavouring many foods particularly meats and bakery products, as well as in preservation, flavouring and garnishing of food. Aframomum melegueta is used as a stimulant and diuretic, in curing ailments such as worms, congested chest, and hypertension (Ndukwu and Ben-Nwadibia, 2005), therefore, the inclusion of these spices in diets can have health promoting benefits.

Many of the works done on condiments and spices in general had been centered on their ethnomedicinal and antioxidant properties with few on their chemical composition (Achi, 2005; Shirin Adel and Prakash, 2010; Elemo et al., 2011; Bamigboye et al., 2012). Much information on nutritional importance of these indigenous spices especially in the area of their micronutrient potentials has not been documented. This study was therefore carried out to evaluate the micronutrient potentials of Allium Ascalonicum, Piper guneensis, Aframomum melegueta, Zingiber officinale, Ocimum basilicum, Allium sativum, and Eugenia caryophyllata commonly consumed in Nigeria.

\section{MATERIALS AND METHODS}

MATERIALS: Samples of Allium Ascalonicum, Piper guineensis, Aframomum melegueta, Zingiber officinale, Ocimum basilicum, Allium sativum, and Eugenia caryophyllata were purchased from Bodija market in Ibadan, Oyo State, Nigeria. Sample of various spices was prepared by removing their shell and non-edible portion and then weighed. The moisture content and vitamin composition of the samples were determined on fresh matter basis while the rest of the samples were dried at $60^{\circ} \mathrm{C}$ for 18 hours using air oven (Gallenkamp, Model OV - 440, England), and then grinded with mortar and pestle. The moisture content and vitamins (from fresh sample) and ash and minerals (dried sample) of the samples were determined in triplicate using the standard methods of analysis of Association of Official Analytical Chemists (AOAC, 1995) and atomic absorption spectrophotometric methods as follows:

\section{METHODS}

The moisture content of the samples was determined by air oven method (Gallenkamp, Model OV - 440, England) at $105^{\circ} \mathrm{C}$. The ash content was determined by weighing $5 \mathrm{~g}$ of sample in triplicate and heated in a muffle furnace at $550^{\circ} \mathrm{C}$ for 4 hours to a constant weight, cooled to about $100^{\circ} \mathrm{C}$ in the furnace and then transferred into a dessicator to cool to room temperature, weighed, and ash calculated as $\mathrm{g} / 100 \mathrm{~g}$ original fresh edible portion. Calcium, iron, and zinc content of the samples were determined spectrophotometrically by using Buck 200 atomic absorption spectrophotometer (Buck Scientific, Norwalk United Kingdom (UK), Essien et al., 1992) and comparing their absorption with absorption of standards of these minerals. Phosphorus was determined by vanado-molybdate colorimetric method (Ologhobo and Fetuga, 1983). The $\beta$ carotene content of the samples was determined through ultraviolet absorption measurement at 328 $\mathrm{nm}$ after extraction with chloroform. Calibration curve of $\beta$-carotene standard solutions was made and the sample $\beta$-carotene concentration estimated as microgram $(\mu \mathrm{g})$ of $\beta$-carotene. Their ascorbic acid content was determined by extracting the samples with 5\% metaphosphoric acid and titrating the extracts with 2, 6-dichlorophenol-indophenol solution. Data obtained were analysed statistically using the procedure of Companion of Medical Statistics (Bamgboye, 2006).

\section{RESULTS}

The moisture and ash content of the seven spices are as shown in Table 1. Four of the spices ( $A$. ascalonicum, $O$. basilicum, $A$. sativum, and $Z$. officinale) were high in moisture content, the values of which were significantly different from each other $(\mathrm{p}<0.05)$. A. melegueta, E. caryophyllata and $P$. guineensis were very low in moisture content with little but significantly different variation in values $(p<0.05)$ since they are normally used in their dry form. A. ascalonicum was highest in moisture content while $P$. guineensis had the lowest. $O$. basilicum had 
the highest ash value while Eugenia caryophyllata had the lowest. Except for $A$. melegueta and $A$. ascalonicum which were not significantly different from each other, significant differences existed between the ash values of the spices $(p<0.05)$.

Table 1: Moisture and ash content of seven selected spices $(\mathrm{g} / \mathbf{1 0 0 g})$

\begin{tabular}{lll}
\hline Spices & Moisture & Ash \\
\hline Allium ascalonicum & $91.10 \pm 0.05^{\mathrm{a}}$ & $0.65 \pm 0.21^{\mathrm{a}}$ \\
Ocimum basilicum & $76.56 \pm 0.03^{\mathrm{b}}$ & $1.77 \pm 0.14^{\mathrm{b}}$ \\
Allium sativum & $75.60 \pm 0.05^{\mathrm{b}}$ & $0.30 \pm 0.14^{\mathrm{c}}$ \\
Zingiber officinale & $64.81 \pm 0.13^{\mathrm{c}}$ & $0.49 \pm 0.00^{\mathrm{d}}$ \\
Aframomum melegueta & $18.28 \pm 0.05^{\mathrm{d}}$ & $0.66 \pm 0.14^{\mathrm{e}}$ \\
Eugenia caryophyllata & $16.09 \pm 0.20^{\mathrm{e}}$ & $0.29 \pm 0.07^{\mathrm{c}}$ \\
Piper guineensis & $15.45 \pm 0.20^{\mathrm{e}}$ & $0.87 \pm 0.00^{\mathrm{f}}$
\end{tabular}

Values are means of three determinations. Figures with the same parenthesis are not significantly different $(p>0.05)$ while those with different parenthesis are significantly different $(p<0.05)$.

Wide variation was observed in the mineral content of the spices with highly significant differences (Table 2). Their calcium content varied widely with highly significant differences, $O$. basilicum having the highest value followed by $P$. guineensis and $A$. ascalonicum $(\mathrm{p}<0.05)$. There was no significant difference in calcium value for $Z$. officinale and $E$. caryophyllata $(p<0.05)$. The values obtained for the iron and zinc content level of the spices were very similar. $O$. basilicum had the highest value of calcium, $\beta$-carotene, and ascorbic acid; $A$. melegueta had the highest value of iron, while $Z$. officinale was highest in phosphorus and zinc content $(p<0.05)$.

Table 2: Some selected mineral and vitamin composition of spices $(\mathrm{mg} / 100 \mathrm{~g})$

\begin{tabular}{lcccccc}
\hline Spices & Calcium & Iron & Phosphorus & Zinc & $\beta$-carotene & Ascorbic acid \\
\hline A. ascalonicum & $350 \pm 28.30^{\mathrm{a}}$ & $0.29 \pm 0.00^{\mathrm{a}}$ & $55.0 \pm 2.83^{\mathrm{a}}$ & $0.10 \pm 0.00^{\mathrm{a}}$ & $113.5 \pm 0.00^{\mathrm{a}}$ & $11.26 \pm 0.00^{\mathrm{a}}$ \\
O. basilicum & $750 \pm 14.10^{\mathrm{b}}$ & $0.33 \pm 0.00^{\mathrm{b}}$ & $230 \pm 0.00^{\mathrm{b}}$ & $0.14 \pm 0.00^{\mathrm{b}}$ & $356.5 \pm 0.30^{\mathrm{b}}$ & $38.25 \pm 0.00^{\mathrm{b}}$ \\
A. sativum & $7.0 \pm 1.40^{\mathrm{c}}$ & $0.27 \pm 0.00^{\mathrm{a}}$ & $95.0 \pm 1.41^{\mathrm{c}}$ & $0.07 \pm 0.00^{\mathrm{c}}$ & $109.5 \pm 0.10^{\mathrm{a}}$ & $9.26 \pm 0.00^{\mathrm{c}}$ \\
Z. officinale & $170 \pm 14.10^{\mathrm{d}}$ & $0.39 \pm 0.00^{\mathrm{c}}$ & $261 \pm 1.4^{\mathrm{d}}$ & $0.15 \pm 0.00^{\mathrm{d}}$ & $226.8 \pm 0.00^{\mathrm{c}}$ & $13.33 \pm 0.00^{\mathrm{d}}$ \\
A. melegueta & $150 \pm 14.10^{\mathrm{d}}$ & $1.26 \pm 0.00^{\mathrm{d}}$ & $133 \pm 1.41^{\mathrm{e}}$ & $0.05 \pm 0.00^{\mathrm{e}}$ & $308.5 \pm 0.00^{\mathrm{d}}$ & $31.26 \pm 0.00^{\mathrm{e}}$ \\
E. caryophyllata & $170 \pm 0.00^{\mathrm{d}}$ & $0.24 \pm 0.00^{\mathrm{d}}$ & $74 \pm 1.41^{\dagger}$ & $0.04 \pm 0.00^{\mathrm{e}}$ & $98.1 \pm 0.10^{\mathrm{e}}$ & $7.23 \pm 0.00^{\dagger}$ \\
P. guineensis & $550 \pm 0.00^{\mathrm{e}}$ & $0.25 \pm 0.00^{\mathrm{d}}$ & $253 \pm 1.41^{\mathrm{g}}$ & $0.07 \pm 0.00^{\mathrm{c}}$ & $287.1 \pm 0.10^{\mathrm{f}}$ & $21.35 \pm 0.00^{\mathrm{g}}$ \\
\hline
\end{tabular}

*Determined as Retinol equivalent

Values are means of three determinations. Figures with the same parenthesis are not significantly different $(p>0.05)$ while those with different parenthesis are significantly different $(p<0.05)$.

Table 3 shows the percentage contribution of some micronutrients from the spices to the Recommended Dietary Allowances (RDAs) of consumers $/ 100 \mathrm{~g}$ edible portion. $O$. basilicum had highest possible contribution of calcium to RDA of consumers followed by $P$. guineensis; and the lowest possible contribution was from $A$. sativum. The highest contribution of $\beta$ carotene and ascorbic acid are from $O$. basilicum and lowest is from $E$. caryophyllata 
Am. J. Food. Nutr, 2013, 3(3): 122-126

Table 3: Percent micronutrient contribution to Recommended DietaryAllowances of Consumers

\begin{tabular}{lrrrrrr}
\hline Spice & \multicolumn{1}{l}{$\begin{array}{l}\text { \%a } \\
\text { 1000mg }\end{array}$} & $\begin{array}{l}\text { \%-Carotene } \\
\text { 1000 RE }\end{array}$ & \%RDA & $\begin{array}{c}\text { Ascorbic acid } \\
60 \mathrm{mg}\end{array}$ & \%RDA \\
\hline A. ascalonicum & 350 & 35.0 & 113.5 & 11.4 & 11.3 & 18.8 \\
O. basilicum & 750 & 75.0 & 356.5 & 35.7 & 38.3 & 63.8 \\
A. sativum & 7 & 0.7 & 109.5 & 11.0 & 9.3 & 15.4 \\
Z. officinale & 170 & 17.0 & 226.8 & 22.7 & 13.3 & 22.2 \\
A. melegueta & 150 & 15.0 & 308.5 & 30.9 & 31.3 & 52.1 \\
E. caryophyllata & 170 & 17.0 & 98.1 & 9.8 & 7.2 & 12.1 \\
P. guineensis & 50 & 55.0 & 287.1 & 28.7 & 21.4 & 35.6 \\
\hline
\end{tabular}

(R.E. = Retinol Equivalent)

\section{DISCUSSION}

The values obtained for the moisture content of the spices (Table 1) are in agreement with the values obtained for fresh vegetables, (Ihekoronye and Ngoddy, 1985). Fresh vegetables are always high in moisture content, which is a measure of its freshness. The high moisture content of four of the spices ( $A$. ascalonicum, $O$. basilicum, $A$. sativum, and $Z$. officinale) underscores their perishability and susceptibility to microbial spoilage, and the need for proper preservation to prevent their spoilage. However, the low moisture content of $A$. melegueta, $E$. caryophyllata and $P$. guineensis indicates their possible long shelf life. Except for $O$. basilicum, the ash values of the spices were very low. This was an indication that the spices may be low in mineral content, especially the macro minerals. The ash value of $O$. basilicum was suggestive that the spice might be a good source of minerals.

The values of selected minerals and vitamins of the spices are as shown in Table 2. There were significant differences in the values of the minerals in all the spices. $O$ basilicum was very high in values of the macrominerals studied, while $P$. guineensis and $A$. ascalonicum were high in calcium, higher than the value reported for fermented Parkia biglobosa (locust bean, a popular traditional condiment, (Elemo et al., 2011)) and can be good sources of this mineral. $Z$. officinale and $A$. melegueta were relatively high in calcium and can also serve as sources of this mineral. A. sativum is a very poor source of calcium. Except $A$. sativum, all the spices studied had higher calcium value than the values re3ported for some fruits, seeds and leaves of some plant species at Umudike, Nigeria (Dike, 2010), while their phosphorus content were much comparable.
Incorporation of these spices into the diet can serve as means of meeting substantial part of daily calcium requirements of their consumers. Calcium is an important mineral needed for maintenance of strong bones and teeth, as well as stimulating the liver and beneficial to the heart and nervous system (Whitney et al., 1996; Ndukwu and Ben-Nwadibia, (2005)).

The value obtained for calcium and phosphorus in $Z$. officinale in this study were significantly higher than the ones reported by Shirin Adel and Prakash (2010) and Bamigboye et al., (2012), while the zinc and iron content were significantly lower. This observed difference might be due to variation in soil conditions from the source of production, and the level of moisture content of the sample which varies depending on length of storage. Ocimum basilicum, $Z$. officinale, and $P$. guineensis phosphorus content were higher than that of Parkia biglobosa (Elemo et al., (2011). Z. officinale, $O$. basilicum and $A$. melegueta can be good sources of phosphorus, which is required for prevention of bone mineral loss, decreased growth and poor tooth development (Whitney et al., 1996).

All the spices studied were poor sources of iron and zinc and cannot make significant contribution to intake of these mineral. All the spices studied were good sources of $\beta$-carotene. This may have resulted at least in part from their colour (Bowman and Russell, 2001). Their high $\beta$-carotene content can qualify them as good sources of this provitamin $A$ which is a micronutrient of great nutritional importance.

The ascorbic acid content of the spices was also relatively high. $\beta$-Carotene and ascorbic acid have been implicated in antioxidant activity, which is beneficial to the human body (Halliwell, 1997), hence 
these spices may possess antioxidant characteristics. The $\beta$-carotene and ascorbic acid content of the spices might have accounted for the health promoting properties adduced to them.

Overall, $O$. basilicum can contribute the highest percentage of the vitamins and minerals studied.

\section{CONCLUSION}

The spices were rich in some micronutrients and can be good sources of meeting part of recommended dietary allowances (RDAs) for calcium, $\beta$-carotene and ascorbic acid, but are poor sources of iron and zinc which are required for prevention of anaemia and promoting growth especially among children. However, since they do not constitute major food ingredients but are used as condiments, the dietary requirements of these minerals can be met from other food sources. Because of the micronutrient and antioxidant potentials of these spices, their consumption in whole or use as condiments should be encouraged as means of dietary diversity in ameliorating micronutrient deficiencies.

\section{REFERENCES}

Achi, O. K. (2005). Traditional fermented protein condiments in Nigeria. African J Biotechnol; 4(13), 1612-1621.

Achinewu, S. C, Aniena, M. I, Obomanu, F. G. (1995). Studies on spices of food value in the South Eastern of Nigeria 1: Antioxidants properties. J. African Med. Plants 18: 135-139.

Association of Official Analytical Chemists (AOAC) (1995). Official Methods of Analysis of AOAC International, $16^{\text {th }}$ edn Vol II

Bamigboye, A. Y., Adepoju, O. T., Oyinsan, O., Kabir. H. (2012). Micronutrient potentials and contribution to nutrient intake of four commonly consumed local condiments and spices in South-western Nigeria. Nig $J$ Nutri Sci 33 (1), 57 - 61.

Bamgboye, E. A. (2006). A companion of medical statistics, $1^{\text {st }}$ edn. Folbam Publishers, Ibadan; Pp $35-48$.

Bowman B. A. and Russell R. M. (2001). Present knowledge in nutrition. $8^{\text {th }}$ edn. Washington, DC:International Life Sciences Institute. Pp 128-180.

Dike, M. C. (2010). Proximate, phytochemical and nutrient compositions of some fruits, seeds and leaves of some plant species at Umudike, Nigeria. ARPN J Agric Biol Sci 5 (1), $7-16$.

Eileen, K, Venkatesh, M. and Venkatesh I (2003). Alleviating hidden hunger - Approaches that work. IAEA Bulletin 45/1.
Elemo, G. N., Elemo, B. O, Oladunmoye, O. O, and Erukainure, O. L. (2011). Comprehensive investigation into the nutritional composition of dehulled and defatted African locust bean seed (Parkia biglobosa). African Journal of Plant Science 5 (5), 291-295.

Encyclopedia of Food Science \& Technology (1999). New York, John Wiley \& Sons. Vol 4, Pg 2410.

Essien, A. I., Ebana, R. U. B and Udo, H. B. (1992). Chemical evaluation of pod and pulp of the fluted pumpkin (Telfaira occidentalis) fruit. Food Chem. 45, 175-178.

Fayemi, P. O. (1999). Nigerian vegetables. $1^{\text {st }}$ edn, Heinemann Educational Books, Ibadan. Pp 161-173.

Grzanna, R., Lindmark, L. and Frondoza, C. (2005). Ginger-A herbal medicinal product with broad antiinflammatory actions. J. Med. Food, 8(2): 125-132.

Iwu, M. M. (1993). Handbook of African medicinal plants. Boca Raton CKC Press. Free Enterprise Publishers, Lagos, P435

Macmillan, H. F. (1984). A handbook for tropical planting and gardening. $4^{\text {th }}$ edn. MacmillanScientific Publishers, London. P 326

Ndukwu, B. C. and Ben-Nwadibia, N. B. (2005). Ethno medicinal aspects of plants used as spicesand condiments in the Niger Delta area of Nigeria. $J$ African Med Plants 25.

Ologhobo, A. D. and Fetuga, B. L. (1983). Investigation on the trypsin inhibitor, hemagglutinin, phytic and tannic acid contents of cowpea Vigna Unguiculata. Food Chem. 12 (4), 249-254.

Sop, M. M. K, Fotso, M, Gouado1, I, and Tetanye, E and Amvam Zollo, P. H. Nutritional survey, staple foods composition and the uses of savoury condiments in Douala, Cameroon 2008

Shirin Adel P. R.and Jamuna Prakash (2010). Chemical composition and antioxidant properties of ginger root (Zingiber officinale). J Med Plants Res, 4 (24), 26742679.

Underwood, B. A. (1999). Micronutrient deficiencies as a public health problem in developing countries and effectiveness of supplementary, fortification and nutrition education programme: Is there a role for Agriculture? A Workshop hosted by the International Rice Research Institute. Los Banos, Philippines. October 5-7, 1999.

Wardlaw, G. M. and Kessel, M (1999). Perspectives in nutrition. Fourth edn. WCB / Mc Graw Hill Companies Inc. USA P57.

Whitney, N. E., Cataldo, B. C., Debruyne, K. L. and Rolefes, R. S. (1996). Nutrition for health and health care. West Publishing Company, New York. Pp 139140, 161-164, 184-195. 